\title{
DE STATUS VAN PIEKIE-NJAN
}

DOOR

PH. A. SAmson

Bij Publicatie van 10 Juli 1829, Gouvernementsblad No. Io, werden door Gouverneur CANTZ'LAAR ${ }^{1}$ ) bepalingen afgekondigd ten aanzien van slaven, die geen meester hebben.

Artikel 1 van deze, zowel in het Nederlands als in het NegerEngels gestelde publicatie, schreef voor dat ,,alle zoodanige Slaven en Slavinnen te Suriname, die geenen Meester hebbende, evenwel geene Brieven van Vrijdom verkregen hebben en ten Kantore van de Registratie der Slaven niet bekend staan, onverschillig uit welke oorzaak zulks is ontstaan, hetzij dat zij zich hebben vrijgekocht, door hunnen Meester aan zich zelve overgelaten zijn of anderszins", vóór 31 December 1829 moesten worden geregistreerd.

Indien deze registratie werd verzuimd, vervielen de slaven, die geen Meester hadden, aan den Lande.

De slaven, die geen Meester hadden, waren bekend onder de naam piekie-njan, hetgeen betekent: voedsel opscharrelende.

Over de rechtstoestand van zulke slaven is niet veel bekend.

Op 23 Juli 1845 wees het Hof van Justitie in Suriname een vonnis, waarin over de staat van slaven, die geen meester hadden, een beslissing werd genomen. Van dit vonnis werd hoger beroep ingesteld op de Hooge Raad der Nederlanden en op 7 Mei 1847 werd in deze zaak, die door de redactie van het Weekblad van het Recht een zonderling, maar hoogst belangrijk rechtsgeding werd genoemd, arrest gewezen.

Hieronder volgen de feiten.

Mejuffrouw C. S. Baumgartner had bij een testament, op 17 Juni 1821 in Suriname gepasseerd en in 1822 met de dood bekrachtigd, het volgende bepaald:

„Ik legateer, make en bespreke aan mijne neger-slavinnen Cecilia en Charlotta de vrijheid, welke bekend is in deze

1) Paulus Rudolf Cantz'laar was Gouverneur-Generaal van 20 Mei 1828 tot 15 December 1831; hij overleed te Paramaribo. 
kolonie onder den naam PIEKIE-NJAN en welke aan haar zal worden gegeven, namelijk aan CECILIA dadelijk na mijn afsterven, en aan CHARLOTTA na overlijden mijner moeder, en ingevalle van dezer vooroverlijden, dadelijk na mijn overlijden, met dien verstande, dat ingevalle zij in staat zullen zijn of komen, de kosten van het obtineren van brieven van vrijdom en manumissie op te brengen en te fourneren, zoodanige brieven door mijn executeur aan den Hove van Politie en Criminele Justitie zullen worden verzocht, doch niet anders dan wanneer zij respectievelijk daartoe de noodige kosten dragen en voldoen".

Tot executeur van de nalatenschap van mejuffrouw BAUMGARTNER werd benoemd M. I. RoBlES.

In 1845 werd door de slavin Cecilia, aan wie kosteloos een praktizijn was toegevoegd, een proces tegen genoemde executeur gevoerd.

De eiseresse stelde dat door de executeur aan haar geen kennis was gegeven van het testament van mej. BAUMGARTNER en dat, doordat zij onbekend was met de voorwaarden waaronder zij de vrijheid had kunnen bekomen, zij die executeur als slaaf was blijven dienen.

Cecilia had respectievelijk op 13 Januari 1825 en 25 October 1827 een zoon en dochter ter wereld gebracht; deze kinderen waren door de boedel Baumgartner als slaven beschouwd en behandeld en de zoon KAREL was aan een stiefzoon van de executeur J. NunEs, verkocht. Door een toeval werd CECILIA bekend met de testamentaire beschikking van haar meesteres en zij vorderde van executeur en pleegzoon, haar zoon terug, met alle vruchten en baten tot de overgifte toe.

Gedaagden stelden zich op het standpunt dat Cecilia en haar zoon gedurende de staat van piekie-njan slaven bleven.

Bij vonnis van het Hof van Justitie dd. 23 Juli 1845 werd de vordering ontzegd.

Het Hof was van oordeel dat de beslissing afhankelijk was van de beantwoording van de vraag of de moeder recht had op de zoon, die zij in de staat van piekie-njan ter wereld had gebracht. Deze vraag werd ontkennend beantwoord. Het Hof overwoog dat de staat van piekie-njan geen wettig erkende staat is, maar een ingeslopen misbruik of een fictieve manumissie, waardoor de tot de wettige vrijlating voorgeschreven formaliteiten ontdoken werden. Tijdens de geboorte van haar zoon verkeerde CECILIA in die niet-wettige staat en bezat dus de vrijdom 
niet, maar bleef slavin van de erfgenamen van haar meesteres. Aangezien al wat uit een slavin werd geboren, aan de meester toebehoort, moest dus de uit CECILIA geboren zoon KAREL als een slaaf worden aangemerkt.

Uit de voor het Hof gewisselde stukken kan worden afgeleid dat in 1836 de boedel Baumgartner voor CECILIA brieven van manumissie had verkregen en de kosten daarvan door een zekere J. HAZENBROEK waren terugbetaald.

De praktizijn van CEcILIA nam met het vonnis van het Hof geen genoegen en ging in appèl bij de Hooge Raad der Nederlanden. Twee bekende advocaten verdedigden de belangen van partijen; voor appelante kwam op Mr WinTGENs, voor de tegenpartij Mr vaN GIGCH.

De pleidooien van de advocaten zijn in het Weekblad van het Recht van 31 Mei 1847 opgenomen.

Mr Wintgens deelde mede dat Cecilia, toen zij in 1836 vernam dat zij sedert 1822 ten onrechte in slavernij had verkeerd, een aanklacht bij de Procureur-Generaal tegen de executeur van de boedel Baumgartner indiende, doch deze klacht bleef onvervolgd; een bewijs dat arme, verongelijkte negers niets konden uitrichten tegenover de ,,aristocratie de la peau”. Uit zijn pleidooi blijkt dat men in Suriname, wanneer men een slaaf de vrijheid wilde schenken, om het recht van f 300 tot f 500 dat voor de brieven van manumissie moest worden betaald te ontduiken, de slaaf aan zich zelven verkocht of hem het recht van piekie-njan toekende. Had men de gelegateerde vrijheid niet verzwegen, dan zou CECILIA gebruik gemaakt kunnen hebben van het in 1829 aan slaven zonder meester toegekende recht om zich te laten registreren.

Mr van Gigch zeide in het feitelijk gedeelte van zijn pleidooi dat hij voorzien had dat men in deze zaak zou trachten een aandoenlijk toneel te schetsen; hij wees er op dat het in Suriname vaak veel beter voor een slaaf was, om een zachtzinnige meester toe te behoren en tegen arbeid van het nodige te worden voorzien, dan quasie in het genot van de vrijheid, zonder enig middel van bestaan, rond te zwerven onder leiding van een vadsige, zedeloze moeder, die zelve niet in haar behoeften kan voorzien.

De Hooge Raad gaf een zeer gemotiveerde beslissing en overwoog dat ter beslissing van het geschil moest worden vastgesteld in welke staat CEcilia door de making der vrijheid bekend onder de naam van piekie-njan is gebracht, en de vraag moet 
worden beantwoord of uit kracht van de erfstelling de boedel Baumgartner eigenaar werd van de slavin en tengevolge daarvan van haar zoon. Een bevestigende beantwoording van deze vraag zou volgens het Hoge College in strijd zijn met de woorden van de beschikking; bovendien moet de staat van piekie-njan beschouwd worden als een ontslag uit het bestaande meesterschap en het stellen op vrije voeten, zodat deze personen volgens artikel 1 van de Publicatie van 10 Juli 1829 slaven zonder meesters worden. Door de beschikking was de slavin gekomen in een toestand dat zij haar eigen meesteresse werd en voor zich zelve de kost kon verdienen, daar zij anders nooit de middelen zou kunnen bekomen, om brieven van manumissie te vragen.

Uit deze beslissing volgt, dat de boedel evenmin aanspraak kon maken op kinderen, die door CEcILIA in de staat van piekienjan waren ter wereld gebracht.

Het vonnis van het Hof van Justitie werd vernietigd en de executeur werd veroordeeld om ,zijn handen te trekken en te houden" van KAREL en aan CECILIA te restitueren alle vruchten, baten en profijten van de slaaf genoten en de kosten van het geding.

Het gevoerde proces is merkwaardig, omdat het ons een kijk geeft op de toestanden die vóór de Emancipatie der slaven in Suriname heersten en de misbruiken die uit het houden van slaven ontstonden.

\section{S U M M A R Y}

\section{„The STAtus of PIEkie-nJan"}

In Suriname there existed, in the first half of the 19th century, a class of slaves, male and female, who did not belong to anyone and yet were not set free bij letters of manumission. They had nobody to look after them and so they had to provide for themselves, had to find their own food. The caracteristic name, in Negro-english, for these people was piekie-njan (piekie $=$ to pick, to pick up, to hunt up; njan = to eat, food).

As early as the year 1829 the Suriname government published an ordinance decreeing that all such persons, whose names did not appear in the slave registers, ought to be registered before December 31, 1829; if omitted they would become government property.

A will of the year 1821, in which the term piekie-njan was used, gave cause to a remarkable legal proceeding. The testatrix, a lady who died in 1822, had by her last will and testament bestowed on her female slave Cecilia the freedom which in the colony was known as piekie-njan. As soon as Cecilia would be in a position to pay the costs which the acquisition of a letter of manumission involved, such letter of freedom should be applied for by the lady's executor. 
In 1845 , so 23 years afterwards, Cecilia started a law suit against the executor, who, as she stated, had never acquainted her with the terms of the will, so that she had continued to serve as a slave, even as a slave of the executor. In the meantime she had given birth to two children, a son and a daughter, who had been considered and treated by the heirs of the deceased lady as slaves, belonging to the estate; the boy had even been sold to a relative of the executor.

When, by pure chance she had become acquainted with the terms of the will, Cecilia claimed from the executor and his relative the restitution of her son, with all proceeds and assets up to the time of his surrender. Defendants however took the view that during her state of piekie-njan Cecilia and her son had remained slaves.

The Court of Justice denied the claim, ruling that piekie-njan was no acknowledged status, but an abuse, an illegal manumission, by which the regular formalities for setting a slave free, were evaded. At the time of the birth of Cecilia's son the mother was still a slave, belonging to the estate of her deceased mistress. As all off spring of a female slave were the property of her proprietor, the son of Cecilia must be considered a slave.

From the papers exchanged during the process, however, it may be infered that in 1836 the estate had acquired letters of manumission for Cecilia and that the costs had been repaid by a certain party.

Cecilia's lawyer appealed from the Court of Justice in Suriname to the High Court of the Netherlands in the Hague. Two well-known lawyers pleaded on behalf of plaintiff and defendants.

Cecilia's counsellor stated that her charge in 1836 against the executor was not followed by legal proceedings, by which it was proved that poor injured negroes were powerless against ,,the aristocracy of the skin". When in Suriname one wished to free a slave, in order to evade the costs of manumission, 300 to 500 guilders, he was sold to himself, or granted the status of piekie-njan. Had not the testamentary disposition been concealed from Cecilia, she could have applied for registration in accordance with the ordinance of 1829 .

The Court decided that, if Cecilia had to be considered as a slave, belonging to the estate, such would be in direct defiance to the wording of the will; moreover that the status of piekie-njan should be held as one of being released from the position of slavery and of having become free persons, without masters, according to the ordinance of 1829. Since the death of the testatrix Cecilia had been her own mistress, in a position to earn her own living, without which she could never obtain the means to apply for a letter of manumission. Accordingly Cecilia's children, born during the mother's state of piekie-njan, could no more than Cecilia herself be claimed as slaves belonging to the estate.

The executor was sentenced to „keep his hands off the son" and to repay to the mother all profits gained from the so called slave, as well as to pay the costs of the law-suit.

Aforesaid suit is remarkable in giving an insight into certain conditions prevailing in Suriname before the emancipation and in disclosing one of the abuses the institution of slavery was accompanied with. 